\title{
Development of a sustainable environmentally friendly waste management system at large mass and sports events (2023 WJC in Novosibirsk)
}

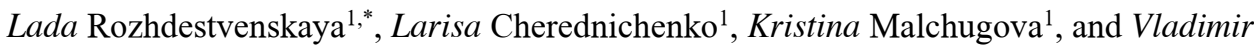 \\ Korotenko ${ }^{2,3}$ \\ ${ }^{1}$ Novosibirsk State Technical University, Prospekt K. Marksa, 20, 630073 Novosibirsk, Russia \\ ${ }^{2}$ Adam University, M. Gvardiya blvd. 55, 720010 Bishkek, Kyrgyz Republic \\ ${ }^{3}$ National Academy of Science KR, Chui ave. 256-a, 720071 Bishkek, Kyrgyz Republic
}

\begin{abstract}
Large public events (forums, championships, contests, olympiads) are events with a large number of spectators and participants, which, as a rule, leads to the generation of a large amount of waste. Mass sporting events are no exception, and when planning them, a special role is assigned to the creation of environmentally friendly waste management system. The subject of the research is the concept of waste management at the upcoming World Junior Ice Hockey Championship in 2023 in Novosibirsk. The article also discusses the types of waste generated in the functional areas of the competition grounds, studied the practice of handling solid waste: possible technologies for utilization and collection. The scheme of waste management at various stages of sports competitions is presented. Reasonable waste management should be based on the following principles: waste minimization, repair and restoration of faulty equipment and inventory, reuse of goods and materials, maximum recycling and composting, minimum burial and storage at landfills. Based on the results of the article, the main methods and recommendations for effective waste management at WJC-2023 were identified
\end{abstract}

\section{Introduction}

The problem of rational consumption of resources, reduction of waste at different stages of production, processing and distribution of the planet's resources is at the epicenter of global attention and affects most of the SDGs [1,2,3]. The search for the most effective models for building a reusable (circular) economy, including within the framework of the European Green Deal $[4,5]$, which involves not only minimizing all types of waste, but also creating methods and technologies for their complete disappearance, is of no less scientific interest and public interest. in perspective.

According to the Federal Classification Catalog of Wastes [6], they are divided according to the areas of activity in which they arise when creating food resources, when

\footnotetext{
*Corresponding author: lada2006job@mail.ru
} 
extracting minerals, in manufacturing, when consuming resources and providing various kinds of services. Also, classifiers that emit varying degrees of hazardous properties (toxicity) of waste are classified as the most commonly used in the world. So in the approaches of the Environmental Protection Agency breaks it down by four characteristics: ignitability, corrosivity, reactivity, toxicity. It is on the basis of approaches to determining the hazard by the degree of negative impact on the environment that the appropriate method of waste management is selected and implemented. At the same time, it is worth answering that in Russia it is not customary to use the "waste declaration" used in many countries of the world, although it is the certification of waste that is the basis for the systematization of work on waste stream management, incl. to reduce them. In general, from the point of view of creating Waste Management System (WMS), all waste is usually divided into four major categories of waste: municipal solid waste, industrial waste, agricultural waste and hazardous waste.

A special type of activity that generates a large amount of waste is mass sports competitions (Olympiads, world championships, etc.), in which the amount of waste increases as the number of spectators increases. The predominant part of waste generated during mass events is mainly related to municipal solid waste (MSW) is consumer waste generated by the population, including during cooking, cleaning and repairing residential premises, maintaining adjacent territories and common areas, keeping pets and birds in residential premises, as well as obsolete, worn out household items [7]. In his article, Thai colleague Atchariyasopon K. cites the following data: at the Premier League games in 2012, on average 1 spectator left behind $0.097 \mathrm{~kg}$ of solid waste [8] According to UNLEASH,

Another, poorly studied in the hospitality industry, is the topic of food waste, although a high proportion of this part of waste is of concern worldwide, not only in connection with its harmful effects on the environment (Sustainable Development Goals 6, 12, 13 and 15), but also in connection with the demonstrated inefficiency in the use of natural resources and food stocks, which raises questions of food security and raises concerns for the future sustainability of the international food sector (Sustainable Development Goals 2, 11) [10]. In particular, it is difficult not only to assess the total volume, but also the dynamics of food waste generated in the catering sector. Research carried out in Russia shows that on average a restaurant produces about 14 tons of food waste per year, and the annual industrial waste is at least 1.23 million tons, or $7 \%$ of the total waste in the country [11]. Most food waste comes from overproduction of prepared meals and leftovers from food guests. Best practices in food waste management to reduce waste primarily involve providing incentives to customers for clean plates and partnerships with local farmers in a multi-stakeholder manner. These zones of cooperation bring together food service providers, farmers and charities [11].

Collection of solid household waste (MSW) in Russia was carried out according to three traditional schemes: without the use of containers, with the use of non-replaceable containers, with the use of replaceable containers [12]. A key aspect in building an effective waste management system is the introduction of a separate waste collection system. This system includes the separation of all waste into recyclable and non-recyclable. Recyclable waste consists of recyclable and recyclable materials and includes plastic and glass bottles, aluminum and cans, paper (paper, cardboard, newspapers, magazines, books, etc.), glass and broken glass. used batteries and accumulators, used vegetable oil (frying fat), filmbased packaging (polyethylene, bubble wrap, stretch film, etc.), wood products (wire spools, used pallets) [13].

An analysis of cross-country waste management practices at sporting events confirms the emphasis on a separate waste collection facility as the basis for an adequate WMS. Thus, a study of the process of collecting and recycling solid waste at the Maratona 
Alzheimer marathon (Mercato Saraceno, September 2019) in Italy showed that less than $15 \%$ of the plastic collected at events is suitable for recycling. This is due to the fact that this type of waste is not sorted by type of plastic, although it requires different methods of processing. For this reason, the researchers developed a project called CORRIPULITO, which involved the separation of plastic by spectators and other participants at the waste collection stage. The project included both informational training of participants, and installation of separate containers for 4 types of plastics with the organization of waste sorting by volunteers. Despite the labor intensity, the CORRIPULITO project proved to be quite effective and the ratio of recycled plastics was higher than in previous years of the Maratona Alzheimer, which, from an environmental point of view, reflects the positive results of this initiative. [14]

In Russia, the experience in waste management based on sorting during major sporting events was analyzed using the example of the Confederation Cup (Moscow, St. Petersburg, Sochi, Kazan, summer 2017). In sports arenas, two types of containers were installed: yellow for recyclable materials (this includes plastic bottles, glasses, glass holders) and green for non-recyclable waste (contaminated wrappers, napkins, packaging containers, etc.) [15]. This sorting system was later implemented at the 2018 FIFA World Cup Russia.

As part of the concept developed for the World Cup, all waste was divided into 9 main types: plastic, glass, broken glass, metal, wood, paper, batteries (batteries), oil, film. In the service areas, activities of the Organizing Committee, partners and service providers, a multi-stream system for separate waste collection was used by color indication of waste containers. At the same time, to simplify collection at the main venues, such as spectator stands, entrance areas, food and hospitality areas, only 2 containers were used: yellow for recyclable waste, and gray for non-recyclable (food waste, stained wrapping paper, napkins, personal hygiene items, etc.) [9]. At each of the 12 stadiums hosting matches, at least 500 sets of containers were installed, including technical zones (each includes two - one for recyclable and the other for non-recyclable waste). About 35 environmental volunteers took part in the collection and sorting of waste in the fan zone. According to statistics, one person (it does not matter, a fan, volunteer or event organizer), on average, leaves at the stadium from $0.02-0.03$ to $3 \mathrm{~kg}$ of garbage per day [13].

In general, an idea of the ratio of the components of garbage and waste of mass sports events can be obtained on the basis of a graphical interpretation of the data presented in Figure 1 [16].

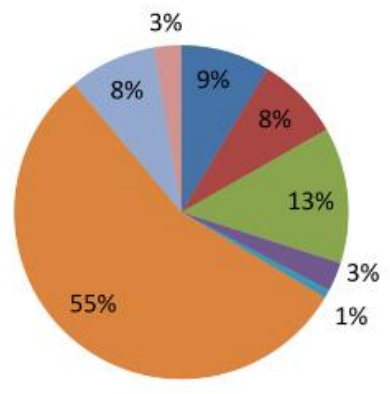

necyclable Paper
non recyclable paper
n Reyclable plastic
n Non Recyclable Plastic
= Refundable beverage
- Food
= Mixed
= Other

Fig. 1. Percentage composition of waste from mass sports events [16]

The concern of government organizations and the public about the impact of mass sporting events on the environment is undoubtedly reflected in the relevant legislative and regulatory documents. Thus, the Waste Framework Directive of the European Commission, updated in May 2018, set a common goal for EU member states to bring the level of internal recycling to $65 \%$ by 2035 . The goal is to avoid landfills and reduce incineration. 
Due to this, innovative and efficient systems for the separate collection of waste have already been introduced in many countries of the world, especially in the EU countries, which ensures a higher level of recycling of each type of waste [17].

Garbage collected and stored at landfills can have a negative impact on living organisms, contaminating soil and groundwater. Incineration of household waste produces greenhouse gas emissions that negatively affect the purity of the Earth's atmosphere and increase the greenhouse effect. These data clearly show the need for an environmentally friendly waste management system, especially in such cases of mass and one-time waste generation, such as at sports events. In accordance with the UN Sustainable Development Goals, which are a kind of call to action from all countries, and aimed at improving the welfare and protection of our planet, it is necessary to increase attention to the problem of the impact of major sporting events on the environment [10].

In 2012, the International Olympic Committee (IOC) published a document entitled "Sustainability Through Sport. Implementation of the Agenda of the Olympic Movement for the XXI century - 2012", according to which MSW should not just be sent to a landfill, but include consistent minimization of waste, preliminary sorting, collection, processing, composting, recovery (extraction of useful components for their reuse [18]) and energy utilization of waste (the use of municipal solid waste as a renewable energy source (secondary energy resources) after the extraction of useful components from them at processing facilities [18]), processing and, only then, disposal.

The FIFA also has special requirements for the management and disposal of waste generated at the FIFA World Cup. So, the organizers of competitions in Russia in 2018 in this matter had to be guided by such documents as [13]:

- $\quad$ FIFA Cleaning and Waste Management Guidelines;

- $\quad$ FIFA Sustainability Projects and Services Guide;

- Sustainable Development Strategy for the 2018 FIFA World Cup in Russia;

- 2018 FIFA World Cup Sustainable Development Policy;

- $\quad$ Federal Law "On Environmental Protection" dated 10.01.2002 N 7-FZ;

- $\quad$ Federal Law "On Production and Consumption Waste" of June 24, 1998 N 89-FZ

- $\quad$ and other regulatory documents related to waste management.

This article examines waste management at major sporting events in the light of the upcoming 2023 World Junior Ice Hockey Championship in Novosibirsk (WJC - 2023). The article reveals the main points concerning the mandatory issues that require reflection in the waste management concept of the WJC - 2023. This document will allow you to build an effective solid waste management system in accordance with the UN sustainable development goals.

\section{Materials and Methods}

In the presented work, the methods of systemic and structural analysis, operational and strategic analysis were used as research methods. The materials of the study were data presented on the websites of the International Olympic Committee, FIFA, the Federal Service for Supervision of Environmental Management, publications of researchers on waste management at major sporting events.

Based on a preliminary analysis of materials, as well as regulatory and legislative documents, the stages of preparation and holding of the championship, the types of waste generated at sporting events and the main functional areas of the competition grounds, where their sorting and collection should be organized, were identified. Further, appropriate technologies for collection and utilization were proposed for each group of wastes. 


\section{Results and Discussion}

The sources discussed above allow us to provide basic recommendations for the development of a waste management concept at the 2023 World Junior Ice Hockey Championship in Novosibirsk. Taking into account that the glacial arena under construction is designed for 10, 5 thousand spectators and data [13], it is possible to calculate the approximate amount of waste generated after matches: from 3.15 to 31.5 tons.

In total, 11 main functional areas of the competition grounds can be distinguished, which should be taken into account when organizing a waste management system at a sports event. For ease of perception, these sites were included in Table 1. The table also includes the main types of waste generated at each site.

Table 1. Waste types generated in the functional areas of the competition grounds

\begin{tabular}{|c|c|c|c|c|c|c|c|}
\hline Playground & $\begin{array}{l}\text { Plastic and } \\
\text { packaging } \\
\text { films }\end{array}$ & Glass & Metal & Paper & Wood & $\begin{array}{l}\text { Food } \\
\text { waste }\end{array}$ & $\begin{array}{l}\text { Liquids, } \\
\text { batteries, oil, } \\
\text { other waste }\end{array}$ \\
\hline $\begin{array}{l}\text { 1. Checkpoints, } \\
\text { inspection zones }\end{array}$ & bottle & bottle & $\begin{array}{l}\text { aluminum } \\
\text { cans }\end{array}$ & $\begin{array}{l}\text { packaging } \\
\text { materials }\end{array}$ & & $\begin{array}{l}\text { food } \\
\text { waste } \\
\text { and } \\
\text { residues }\end{array}$ & liquids \\
\hline $\begin{array}{l}\text { 2. Food Zones } \\
\text { a) Restaurant } \\
\text { type meals }\end{array}$ & $\begin{array}{l}\text { bottles and } \\
\text { packaging }\end{array}$ & $\begin{array}{l}\text { bottles } \\
\text { and other } \\
\text { types of } \\
\text { glass, } \\
\text { including } \\
\text { broken } \\
\text { dishes } \\
\end{array}$ & $\begin{array}{l}\text { cans as } \\
\text { well as } \\
\text { damaged } \\
\text { metal } \\
\text { cutlery }\end{array}$ & $\begin{array}{l}\text { cardboard } \\
\text { and } \\
\text { corrugated } \\
\text { boxes }\end{array}$ & $\begin{array}{l}\text { wooden } \\
\text { crates } \\
\text { and } \\
\text { pallets }\end{array}$ & $\begin{array}{l}\text { food } \\
\text { waste } \\
\text { and } \\
\text { residues }\end{array}$ & $\begin{array}{l}\text { used } \\
\text { vegetable oil } \\
\text { (frying fat) }\end{array}$ \\
\hline b) canteens & $\begin{array}{l}\text { bottles and } \\
\text { packaging, } \\
\text { plastic } \\
\text { cutlery }\end{array}$ & & cans & $\begin{array}{l}\text { corrugated } \\
\text { boxes }\end{array}$ & & $\begin{array}{l}\text { food } \\
\text { waste } \\
\text { and } \\
\text { residues }\end{array}$ & $\begin{array}{l}\text { used } \\
\text { vegetable oil } \\
\text { (fat for } \\
\text { frying), } \\
\text { other waste } \\
\end{array}$ \\
\hline $\begin{array}{l}\text { c) public } \\
\text { eateries }\end{array}$ & $\begin{array}{l}\text { bottles and } \\
\text { packaging, } \\
\text { plastic } \\
\text { cutlery }\end{array}$ & & cans & & & $\begin{array}{l}\text { food } \\
\text { waste } \\
\text { and } \\
\text { residues }\end{array}$ & other waste \\
\hline d) catering & $\begin{array}{l}\text { bottles and } \\
\text { packaging, } \\
\text { plastic } \\
\text { cutlery }\end{array}$ & & cans & & & $\begin{array}{l}\text { food } \\
\text { waste } \\
\text { and } \\
\text { residues }\end{array}$ & other waste \\
\hline 3. Logistic area & $\begin{array}{l}\text { packaging } \\
\text { of goods } \\
\text { and } \\
\text { equipment, } \\
\text { including } \\
\text { plastic film, } \\
\text { foam, etc. }\end{array}$ & & $\begin{array}{l}\text { metal } \\
\text { structures } \\
\text { and } \\
\text { fasteners }\end{array}$ & $\begin{array}{l}\text { paper, } \\
\text { cardboard } \\
\text { and } \\
\text { corrugated } \\
\text { packaging }\end{array}$ & $\begin{array}{l}\text { boxes } \\
\text { and } \\
\text { pallets }\end{array}$ & & $\begin{array}{l}\text { oiled rags } \\
\text { and } \\
\text { sorbents, } \\
\text { other waste }\end{array}$ \\
\hline $\begin{array}{l}\text { 4. Medical } \\
\text { service areas }\end{array}$ & $\begin{array}{l}\text { plastic } \\
\text { packaging } \\
\text { and dishes }\end{array}$ & $\begin{array}{l}\text { bottles } \\
\text { and } \\
\text { glasses }\end{array}$ & cans & & & & $\begin{array}{l}\text { medical } \\
\text { waste, other } \\
\text { waste }\end{array}$ \\
\hline $\begin{array}{l}\text { 5. Areas for the } \\
\text { sale of goods and } \\
\text { the provision of } \\
\text { non-food } \\
\text { services }\end{array}$ & packaging & & & $\begin{array}{l}\text { paper, } \\
\text { cardboard } \\
\text { and } \\
\text { corrugated } \\
\text { packaging }\end{array}$ & & & other waste \\
\hline $\begin{array}{l}\text { 6. Media center } \\
\text { and areas of } \\
\text { activity of the } \\
\text { Organizers }\end{array}$ & $\begin{array}{l}\text { bottles and } \\
\text { cups }\end{array}$ & & cans & $\begin{array}{l}\text { office } \\
\text { paper and } \\
\text { boxes }\end{array}$ & & & $\begin{array}{l}\text { old batteries, } \\
\text { other waste }\end{array}$ \\
\hline
\end{tabular}


Table 1. Continued

\begin{tabular}{|c|c|c|c|c|c|c|}
\hline $\begin{array}{l}\text { 7. Supply } \\
\text { warehouse for } \\
\text { the opening / } \\
\text { closing } \\
\text { ceremony }\end{array}$ & $\begin{array}{l}\text { packaging } \\
\text { and bottles }\end{array}$ & & $\begin{array}{l}\text { cardboard } \\
\text { and } \\
\text { corrugated } \\
\text { boxes }\end{array}$ & & & $\begin{array}{l}\text { confetti, } \\
\text { tinsel, } \\
\text { banners and } \\
\text { other } \\
\text { decorative } \\
\text { materials, } \\
\text { other waste }\end{array}$ \\
\hline $\begin{array}{l}\text { 8. Design and } \\
\text { signage }\end{array}$ & $\begin{array}{l}\text { plastic } \\
\text { signs }\end{array}$ & & $\begin{array}{l}\text { cardboard } \\
\text { and } \\
\text { corrugated } \\
\text { boxes }\end{array}$ & & & $\begin{array}{l}\text { banners and } \\
\text { stands, } \\
\text { fabric, other } \\
\text { waste } \\
\end{array}$ \\
\hline $\begin{array}{l}\text { 9. } \quad \text { Power } \\
\text { supply zones }\end{array}$ & & & & & & $\begin{array}{l}\text { oiled rags } \\
\text { and } \\
\text { sorbents, } \\
\text { other waste }\end{array}$ \\
\hline 10. Media zone & $\begin{array}{l}\text { equipment } \\
\text { packaging, } \\
\text { bottles and } \\
\text { packaging, } \\
\text { plastic } \\
\text { cutlery }\end{array}$ & cans & $\begin{array}{l}\text { cardboard } \\
\text { and } \\
\text { corrugated } \\
\text { boxes }\end{array}$ & $\begin{array}{l}\text { wooden } \\
\text { spools } \\
\text { from } \\
\text { cables }\end{array}$ & $\begin{array}{l}\text { food } \\
\text { waste } \\
\text { and } \\
\text { residues }\end{array}$ & $\begin{array}{l}\text { old batteries, } \\
\text { used } \\
\text { vegetable oil } \\
\text { (fat for } \\
\text { frying), } \\
\text { other waste }\end{array}$ \\
\hline $\begin{array}{l}\text { 11. IT and } \\
\text { communications } \\
\text { infrastructure } \\
\text { zone }\end{array}$ & $\begin{array}{l}\text { equipment } \\
\text { packaging }\end{array}$ & & $\begin{array}{l}\text { cardboard } \\
\text { and } \\
\text { corrugated } \\
\text { boxes }\end{array}$ & & & $\begin{array}{l}\text { old batteries, } \\
\text { waste } \\
\text { electrical } \\
\text { and } \\
\text { electronic } \\
\text { equipment } \\
\text { (laptops, } \\
\text { monitors, } \\
\text { batteries, ink } \\
\text { cartridges, } \\
\text { cable pieces, } \\
\text { etc.), other } \\
\text { waste }\end{array}$ \\
\hline
\end{tabular}

Taking into account the method of waste sorting at mass sports events, described above, as well as in $[16,19,20,21,22,23]$ and on the basis of the data in Table 1, the main methods of handling them can be distinguished (Table 2). In each case of possible disposal, it is necessary to conclude contracts with the relevant processing plants.

Table 2. Recycling and collection technologies

\begin{tabular}{|c|c|c|c|c|}
\hline \multirow{2}{*}{$\begin{array}{l}\text { Types of } \\
\text { solid } \\
\text { waste }\end{array}$} & \multirow[t]{2}{*}{ Collection technology } & \multicolumn{3}{|c|}{ Treatment technologies } \\
\hline & & Liquidation & Recycling & $\begin{array}{l}\text { Environmentally friendly } \\
\text { "green technologies" }\end{array}$ \\
\hline $\begin{array}{l}\text { Plastic and } \\
\text { packaging } \\
\text { films }\end{array}$ & $\begin{array}{l}\text { Sorting during the } \\
\text { accumulation phase in the } \\
\text { appropriate container } \\
\text { (yellow) }\end{array}$ & Burning & $\begin{array}{l}\text { Pressing followed by } \\
\text { briquetting }\end{array}$ & $\begin{array}{l}\text { Automated sorting; } \\
\text { Granulation (mechanical } \\
\text { grinding); } \\
\text { high temperature pyrolysis }\end{array}$ \\
\hline Glass & $\begin{array}{l}\text { Sorting during the } \\
\text { accumulation phase in the } \\
\text { appropriate container } \\
\text { (green) }\end{array}$ & - & Sorting, recycling & $\begin{array}{l}\text { Recycling of whole glass } \\
\text { containers; } \\
\text { high-temperature } \\
\text { processing of broken glass } \\
\text { (remelting) }\end{array}$ \\
\hline $\begin{array}{l}\text { Metal } \\
\text { (including } \\
\text { cans) }\end{array}$ & $\begin{array}{l}\text { Sorting at the accumulation } \\
\text { stage in a red container }\end{array}$ & - & Recycling & \\
\hline Paper & $\begin{array}{l}\text { Sorting at the accumulation } \\
\text { stage in a blue container }\end{array}$ & Burning & $\begin{array}{l}\text { Recycling within the } \\
\text { framework of } \\
\text { contractual relations } \\
\text { with waste paper } \\
\text { processing plants }\end{array}$ & $\begin{array}{l}\text { Automated sorting; } \\
\text { recycling }\end{array}$ \\
\hline
\end{tabular}


Table 2. Continued

\begin{tabular}{|l|l|l|l|l|}
\hline $\begin{array}{l}\text { Wood } \\
\text { (pallets, } \\
\text { containers, } \\
\text { packaging) }\end{array}$ & Separate storage furning & $\begin{array}{l}\text { Recycling, obtaining } \\
\text { building materials }\end{array}$ & $\begin{array}{l}\text { Production of } \\
\text { briquettes }\end{array}$ \\
\hline $\begin{array}{l}\text { Food } \\
\text { waste }\end{array}$ & $\begin{array}{l}\text { Gathering at catering } \\
\text { facilities }\end{array}$ & $\begin{array}{l}\text { Removal to } \\
\text { landfills }\end{array}$ & $\begin{array}{l}\text { Composting in } \\
\text { landfills }\end{array}$ & $\begin{array}{l}\text { Stadium compost, } \\
\text { or contractual relationship } \\
\text { with farmers }\end{array}$ \\
\hline Frying oil & $\begin{array}{l}\text { Accumulation in special } \\
\text { containers at places of use } \\
\text { in food processing units }\end{array}$ & - & $\begin{array}{l}\text { Further processing } \\
\text { within } \\
\text { thamework of } \\
\text { contractual } \\
\text { relationships with } \\
\text { firms }\end{array}$ & $\begin{array}{r}\text { of } \\
\text { with }\end{array}$ \\
\hline
\end{tabular}

When developing the MWS concept for WJC- 2023, based on the aggregation of international experience, in order to ensure the effectiveness of the process, a headquarters of employees and volunteers should be formed, fully trained on the basis of the developed approaches. An equally important point is the rational purchase and use of the necessary goods. An overabundance of materials can lead to an increase in economic costs and a deterioration in the environmental performance of the event. Repair of equipment (inventory) and its reuse can, on the contrary, reduce costs and positively affect the total volume of waste.

All waste should be classified according to the type of material from which it is made. Garbage that is not suitable for reuse and recycling must be disposed of in accordance with applicable law. Recyclable solid waste must be carefully sorted, and if necessary (if required by the partners of the WJC - 2023) sort the plastic by type of polymer.

Garbage collection must be carried out in containers of different colors, which must also be signed with an icon and a text explanation in two languages (Russian and English). If necessary, volunteers should work at the garbage cans to help the spectators of the championship properly dispose of waste. It is necessary to inform the audience and other participants of the event about the transition to a "green" waste management policy, briefly explaining the basic rules.

It is extremely important to determine the most convenient and comfortable place for the participants of the event for the installation of containers, their number and labeling. The sizes of containers and their location should be convenient for the responsible personnel. The tanks should not fill up too quickly and they should not give off unpleasant odors. There should always be free access to them and a convenient passage. The number of tanks should be sufficient so that participants do not have to look for them or go too far, so as not to provoke disposal in the wrong place. Sports organizers for collecting waste bags from containers should also provide bins for temporary storage prior to sorting and removal from sites.

It is also important to correctly think over the required number of personnel, sufficient to ensure uninterrupted maintenance of order and exclude staff overload, to prevent possible parasitism and reduce economic costs. Each employee (volunteer) must clearly know their responsibilities, the rules for working with this or that equipment (inventory). To ensure the most effective work of the waste management service, a schedule and work plan should be drawn up for each responsible employee. In addition, special attention should also be paid to the internal audit of this service.

As the temporary bunkers fill up, the recycled waste should be removed to specialized industrial sites, where the responsible employees will sort it. This stage is subject to mandatory documentation for further reporting. 
At the stages of cleaning and collecting solid waste, the entire process should be coordinated in order to timely implement the necessary changes and increase the efficiency of the waste management process. All functional areas should be divided into zones for easy monitoring. A coordinator (operator) should be assigned to each zone, who will monitor and introduce changes. He must also generate a report on the amount of waste sent for recycling, reuse and disposal. This information will be used to prepare a report on the organization of an effective waste management system.

In addition, each employee (volunteer) must undergo theoretical and practical training. Theoretical training consists in studying the types of waste and working with them, studying the developed concept and plans, as well as the procedure for eliminating problem situations and maintaining reporting documentation. Practical training consists of inspecting the working area, equipment and tools, as well as participating in testing the developed concept. The training program should be based on the waste management concept of the event and reflect all of its points.

At the end of the World Championship, based on the information collected, a report on the waste management performance of the World Junior Ice Hockey Championship should be prepared. This report is of particular value for future events held in our and other countries, reflecting the goals of sustainable development. The report should be made freely available to future organizers of sporting events in order to improve the results of green policy implementation and adherence to the UN Sustainable Development Goals.

Using the experience of practical recommendations of Waste Management Concept 2018 FIFA World Cup Russia, it can be argued that all products and services should be included in the total volume of purchases and analyzed for their need. Preference should be given to products that can be reused, refurbished or multifunctional, and have the longest shelf life. This will reduce waste during use. From a number of similar goods, preference should be given to those made from recycled (recycled) materials and subject to recycling after use [13].

When selecting logistics service providers, tender documents should include requirements such as: use of lightweight cardboard packaging to minimize transport costs, use of reusable cardboard packaging, use of reusable pallets and recyclable in the event of breakage.

The use of paper media should be kept to a minimum. It is recommended to send invitations and summons electronically. The use of disposable packaging for souvenirs and gift products should be minimized. It is preferable to choose functional souvenirs that can be used in the future and can also be recycled. When manufacturing and ordering any product, preference should be given to recyclable paper over plastic.

Food operators must make every effort to minimize waste. Reduce the amount of disposable tableware and cutlery used, and prohibit the use of drinking straws, tea bags, sugar stirrers and sticks, etc. Ideally, the packaging of all goods should be from the same material, with priority given to paper or cardboard. All plastic packaging should also be made of the same material, such as PET (polyethylene terephthalate) or PP (propylene). To reduce the use of disposable tableware, it is recommended to manufacture and sell reusable glasses with the event logo. For example, beer in stadiums was sold in reusable commemorative glasses with the image of the flags of the playing teams, with the date and place of the match.

To reduce paper use, we recommend duplex printing and small print when appropriate. Banners and signs should be made from recycled or used materials, or biodegradable materials that have the lowest environmental impact [13].

The developed concept and plan for harvesting, collection, storage, sorting and further distribution should be tested before the start of the main activities to confirm their effectiveness and make changes. Taking into account the fact that at present the 
construction of the ice arena for the World Junior Ice Hockey Championship is still underway, three main stages can be distinguished in the waste management concept (Table $3)$.

Table 3. Waste management at the stages of preparation and holding the championship

\begin{tabular}{|c|c|c|}
\hline \multirow{2}{*}{$\begin{array}{l}\text { Stages of } \\
\text { preparation } \\
\text { and holding of } \\
\text { the } \\
\text { championship }\end{array}$} & \multicolumn{2}{|l|}{ Technologies } \\
\hline & Collection of solid waste & Utilization of solid waste \\
\hline \multicolumn{3}{|c|}{ Construction and preparatory } \\
\hline $\begin{array}{l}\text { Construction } \\
\text { at different } \\
\text { stages }\end{array}$ & $\begin{array}{l}\text { technology of separate collection of waste (construction, } \\
\text { household, scrap metal) from construction sites into containers } \\
\text { located on concrete sites (in order to prevent soil pollution); } \\
\text { technology of reuse of auxiliary materials (such as } \\
\text { formwork); technology of combined use of removable and } \\
\text { non-removable formwork } \\
\text { (preventing the formation of construction waste) [17] } \\
\text { Organization of a waste sorting complex (OWC); } \\
\text { The use of environmentally friendly materials }\end{array}$ & Secondary use or recycling \\
\hline $\begin{array}{l}\text { Delivery of } \\
\text { equipment, } \\
\text { furniture, etc. }\end{array}$ & \multirow[t]{2}{*}{$\begin{array}{l}\text { Separate waste collection technology (construction, } \\
\text { household, scrap metal); } \\
\text { Temporary storage until the bins are full }\end{array}$} & \multirow{2}{*}{$\begin{array}{l}\text { Recycling and incineration; } \\
\text { Reuse of containers and } \\
\text { stands, as well as other } \\
\text { possible equipment }\end{array}$} \\
\hline $\begin{array}{l}\text { Installation } \\
\text { and fastening } \\
\text { work }\end{array}$ & & \\
\hline \multicolumn{3}{|c|}{ Preliminary } \\
\hline $\begin{array}{l}\text { Planning and } \\
\text { procurement }\end{array}$ & $\begin{array}{l}\text { Lean planning; } \\
\text { Application of technologies to minimize possible waste; } \\
\text { Introduction of restrictions on the use of plastic materials in } \\
\text { competitions } \\
\text { Use of electronic equipment and reduce paper consumption } \\
\text { Waste paper collection }\end{array}$ & Waste paper recycling \\
\hline $\begin{array}{l}\text { Delivery of } \\
\text { goods and } \\
\text { various } \\
\text { purchased } \\
\text { products in } \\
\text { packaging }\end{array}$ & $\begin{array}{l}\text { Training of employees and volunteers of the cleaning and } \\
\text { waste management service } \\
\text { Use of electronic equipment and reduce paper consumption } \\
\text { Separate waste collection technology }\end{array}$ & $\begin{array}{l}\text { Recycling and incineration; } \\
\text { Reuse of containers and } \\
\text { stands, as well as other } \\
\text { possible equipment }\end{array}$ \\
\hline $\begin{array}{l}\text { Test } \\
\text { (opening of a } \\
\text { sports } \\
\text { complex) }\end{array}$ & $\begin{array}{l}\text { Use of electronic equipment and reduce paper consumption } \\
\text { Restricting the use of plastic materials in competition } \\
\text { Application of technologies to minimize possible waste } \\
\text { Use of a two- and multi-stream solid waste collection system; } \\
\text { Use of colored containers with detailed and understandable } \\
\text { labeling for separate collection of solid waste; }\end{array}$ & $\begin{array}{l}\text { Recycling and incineration } \\
\text { Burial of organic and food } \\
\text { waste and sale of part of the } \\
\text { waste to farms on the basis } \\
\text { of contractual relations; } \\
\text { Composting of } \\
\text { biodegradable materials } \\
\text { carried out by the Supplier } \\
\text { on the basis of a contract; } \\
\text { Disposal of medical waste } \\
\text { by medical services in } \\
\text { accordance with SanPiN } \\
2.1 .7 .2790-10 \text { "Sanitary } \\
\text { and Epidemiological } \\
\text { Requirements for the } \\
\text { Management of Medical } \\
\text { Waste" }\end{array}$ \\
\hline \multicolumn{3}{|c|}{ Main } \\
\hline $\begin{array}{l}\text { A few days } \\
\text { before the } \\
\text { championship }\end{array}$ & $\begin{array}{l}\text { Informing fans about separate waste collection } \\
\text { Application of technologies to minimize possible waste; } \\
\text { Temporary storage until the bins are full }\end{array}$ & $\begin{array}{l}\text { Recycling and incineration; } \\
\text { Reuse of containers and } \\
\text { stands, as well as other } \\
\text { possible equipment }\end{array}$ \\
\hline
\end{tabular}


Table 3. Continued

\begin{tabular}{|c|c|c|}
\hline Match days & $\begin{array}{l}\text { Use of a two- and multi-stream solid waste collection system; } \\
\text { Use of colored containers with detailed and understandable } \\
\text { labeling for separate collection of solid waste; } \\
\text { Attracting volunteers to help fans; } \\
\text { Collection of medical waste by medical services on their own; } \\
\text { Use of electronic equipment and reduce paper consumption } \\
\text { Restricting the use of plastic materials in competition } \\
\text { Application of technologies to minimize possible waste } \\
\text { Temporary storage until the bins are full } \\
\text { Informing fans about separate waste collection }\end{array}$ & - \\
\hline $\begin{array}{l}\text { Between } \\
\text { matches }\end{array}$ & $\begin{array}{l}\text { Sorting waste collected on match days } \\
\text { Use of electronic equipment and reduce paper consumption } \\
\text { Use of a two- and multi-stream solid waste collection system; } \\
\text { Use of colored containers with detailed and understandable } \\
\text { labeling for separate collection of solid waste; } \\
\text { Temporary storage until the bins are full }\end{array}$ & $\begin{array}{l}\text { Burial of organic and food } \\
\text { waste and sale of part of the } \\
\text { waste to farms on the basis } \\
\text { of contractual relations; } \\
\text { Recycling of recyclable } \\
\text { waste } \\
\text { Incineration of non- } \\
\text { recyclable waste }\end{array}$ \\
\hline Final & $\begin{array}{l}\text { Sorting waste collected on match days } \\
\text { Use of electronic equipment and reduce paper consumption } \\
\text { Separate waste collection technology } \\
\text { Temporary storage until the bins are full }\end{array}$ & $\begin{array}{l}\text { Composting of } \\
\text { biodegradable materials } \\
\text { carried out by the Supplier } \\
\text { on the basis of a contract; } \\
\text { Recycling and incineration } \\
\text { Disposal of medical waste } \\
\text { by medical services in } \\
\text { accordance with SanPiN } \\
2.1 .7 .2790-10 \text { "Sanitary } \\
\text { and Epidemiological } \\
\text { Requirements for the } \\
\text { Management of Medical } \\
\text { Waste" }\end{array}$ \\
\hline
\end{tabular}

Figure 2 shows the technologies used at various stages in a graphical form, which allows us to more clearly demonstrate which technologies are used most often and which ones need to be paid the most attention. 


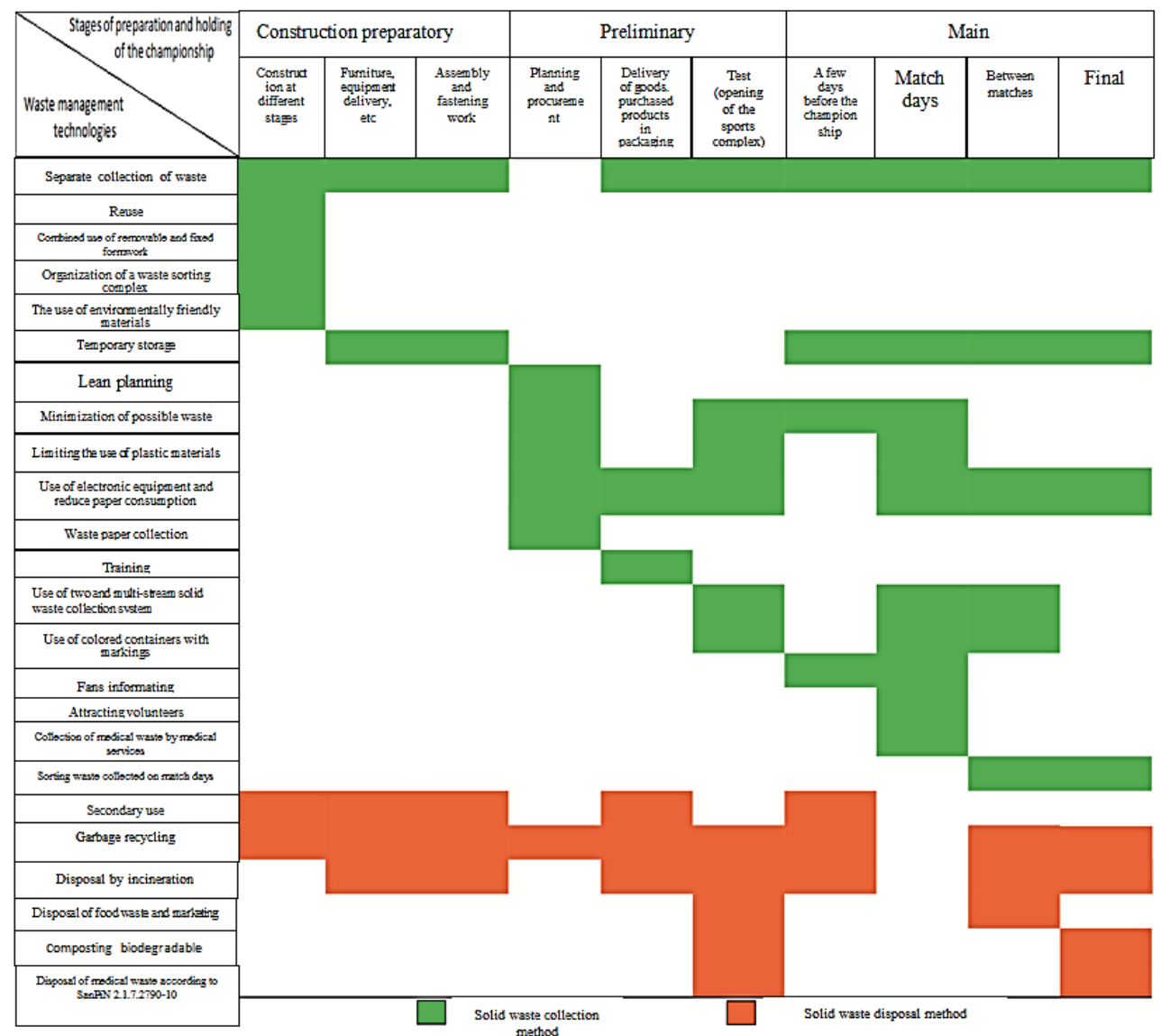

Fig. 2. Waste management at various stages of sporting events

\section{Conclusion}

1. In December 2022, the 47th tournament of the World Junior Ice Hockey Championship will begin in Russia. Competitions will be held in two Russian cities - Novosibirsk and Omsk. One of the factors influencing the quality of the championship is the observance of the principles of using "green" technologies and compliance with the UN Sustainable Development Goals. However, it is difficult to maintain sustainability of events without proper management of events that can have consequences for the economy, society and the environment. The sustainability of mass events is closely related to the logistics of events, including waste management [21].

2. This article describes the ways and methods of waste management at major sporting events. Including the analysis of the experience of the methods used, methods of effective waste collection, sorting and processing and, most importantly, minimization. Based on the materials studied, recommendations were developed for writing a waste management concept at WJC - 2023.

3. This "green" initiative must be supported at all levels of participation of people in a sporting event: from spectators and athletes to organizers and suppliers of goods and services. The application of the above recommendations aimed at the effective 
management of solid waste at major sporting events, including the World Ice Hockey Championship in Russia, increases the ecological culture of the population of the country and the world as a whole, and also reduces the negative consequences of such events.

4. The results of the application of the developed waste management concept at WJC 2023 must be recorded in the reporting documentation for the possibility of subsequent application of proven practices during the preparation and conduct of events of various levels, both in our country and abroad.

\section{References}

1. Chemicals and Waste management: essential TO achieving the Sustainable Development Goals (SDGs)

2. Sustainable Consumption and Production. Global edition. A Handbook for Policymakers, https://sustainabledevelopment.un.org/

3. Waste Connections-2020 Sustainability Report, https://cdn.wasteconnections.com/

4. Circular economy hailed as a driver for reducing food loss and waste, http://www.fao.org/

5. Circular economy: definition, importance and benefits, https://www.europarl.europa.eu/

6. Federal Classification Catalog of Wastes Approved by Order of the Federal Service for Supervision of Natural Resource Use dated July 18, 2014 N 445, https://www.waste.ru/

7. GOST R 53691-2009. "National standard of the Russian Federation. Resource saving. Waste management. Waste passport of I - IV hazard class. Primary requirements"

8. K. Atchariyasopon, Journal of Population and Social Studies, 25 (2017)

9. PlasticsEurope.Plastics-TheFacts2019-Analysis of European plastics production, demand and wastedata. Plastics Europe. https://www.plasticseurope.org/

10. Sustainable Development Goals, https://www.un.org/

11. V. Filimonau, VA Ermolaev, Journal of Cleaner Production, 297 (2021)

12. Technologies for collection and removal of solid household waste, https://www.baurum.ru/

13. Waste Management Concept 2018 FIFA World Cup, https://pdfslide.net/

14. A. Bianchini, J. Rossi, Journal of Cleaner Production, 281 (2021)

15. How Separate Waste Collection Is Organized at the FIFA World Cup, https://recyclemag.ru/

16. J. Rajan, A. Booth, International Journal of Sustainable Development and Planning, 11(3) (2016)

17. A. Salimbeni, Organic waste streams upgrading for gasification process optimization. Substitute natural gas from waste: Technical assessment and industrial applications of biochemical and thermochemical processes, 75 (2019)

18. Federal Law of 24.06.1998 N 89-FZ (as amended on 07.04.2020) "On production and consumption waste" (as amended and supplemented, entered into force on 14.06.2020)

19. N. Tulebayeva, D. Yergobek, G. Pestunova, A. Mottaeva, \& Z. Sapakova, Green economy: Waste management and recycling methods. E3S Web of Conferences, 159 (2020) 
20. Z.B. Razali, Advances in Environmental Biology, 7 (2013)

21. E.A. Jalil, L.S. Hui, K.E Ning, \& L.K. Fai, International Journal of Supply Chain Management, 8(1) (2019)

22. Sustainability through sport. Implementwng the OlympIc movement's Agenda 212012, https://stillmed.olympic.org/

23. M. Nekrasova, A. Mokhov, O. Zholobov, K. Latyshev, Russian journal of resources, conservation and recycling, 3 (2016) 